\title{
ACID PHOSPHATASE AND ZINC TESTS ARE EFFECTIVE FOR SEMEN EXAMINATION AND IDENTIFICATION TO PROVE INTERCOURSE
}

\author{
Ahmad Yudianto ${ }^{1,2,3}$, Ariyanto Wibowo ${ }^{2}$, Indah Nuraini ${ }^{1,3}$, Htet Htet Aung, ${ }^{1,4}$ \\ ${ }^{1}$ Master Program on Forensic Science, ${ }^{2}$ Department of Forensic Medicine \& Medicolegal, Faculty of Medicine, \\ ${ }^{3}$ Human Genetic Study Group, Institute of Tropical Diseases, Universitas Airlangga, Surabaya, Indonesia, ${ }^{4}$ Food \\ and Drug Administration (FDA), Nay Pyi Taw, Myanmar
}

\begin{abstract}
The presence of spermatozoa in vagina is a definite sign of sexual intercourse. However, sometimes microscopic examination does not find spermatozoa or reveals a false negative result. This is influenced by many factors, including the absence of ejaculate in the vaginal canal. In addition, there are other factors such as oligo/azoospermia, vasectomy, degeneration of sperm due to time, incorrect sampling, and improper storage. Therefore, examination of the other components of the ejaculate, ie. the enzyme acid phosphatase, choline and spermin, is important. Compared with spermatozoa, the enzyme phosphatase, choline and spermin have lower evidentiary value because these three components are less specific. However, the level of phosphatase enzyme found in the vagina is much lower than phosphatase enzyme that comes from prostate gland. In this study, as many as 192 samples in the form of patches with sperm/semen stains were tested with acid phosphatase test and zinc test through direct and indirect examination. Washing was carried out using 7 types of detergent for each 4 patch samples, and washing using water as control. The results showed very low sensitivity (0.186) and very high specificity (100\%). This showed that both tests had high specificity values. Acid phosphatase test specifically showed the presence of the enzyme phosphatase, while zinc test specifically showed the presence of zinc in semen. This phosphohydrolase-phosphatase enzyme is easily degraded due to external factors, including temperature, humidity, and chemicals, ie. the element SDS (Sodium Dodecyl Sulfate) that has the ability to cut enzymes. The weakness of the acid phosphatase test is that this enzyme is easily degraded, either partially or completely, due to external factors, such as temperature, humidity, heat, and the presence of chemicals.
\end{abstract}

Keywords: Effectiveness; acid phosphatase test; zink test; identification; semen patch; intercourse

\section{ABSTRAK}

Keberadaan spermatozoa di dalam liang vagina merupakan tanda pasti terjadinya persetubuhan. Namun, kadang-kadang pemeriksaan mikroskopik tidak menemukan spermatozoa atau memberikan hasil false negative. Hal ini dipengaruhi oleh banyak faktor, antara lain tidak adanya ejakulat dalam liang vagina. Selain itu, terdapat pula faktor-faktor oligo/azoospermia, vasektomi, degenerasi dari sperma karena waktu, pengambilan sampel yang salah, dan penyimpanan yang tidak benar. Oleh karena itu, pemeriksaan komponen-komponen ejakulat yang lain, yakni enzim asam fosfatase, kholin dan spermin, menjadi penting. Bila dibandingkan dengan spermatozoa, enzim fosfatase, kholin maupun spermin memiliki nilai pembuktian lebih rendah sebab ketiga komponen tersebut kurang spesifik. Namun, kadar enzim fosfatase yang terdapat dalam vagina jauh lebih rendah dibandingkan dengan enzim fosfatase yang berasal dari kelenjar prostate. Pada penelitian ini sebanyak 192 sampel berupa potongan kain dengan bercak sperma/semen dilakukan pengetesan dengan tes asam fosfatase dan tes zink melalui pemeriksaan langsung dan tak langsung. Pencucian dilakukan menggunakan 7 jenis deterjen untuk masing-masing 4 sampel bercak, dan pencucian dengan air sebagai control. Hasil menunjukkan sensivitas sangat rendah (0.186) dan spesifisitas sangat tinggi (100\%). Hal ini menunjukkan kedua tes tersebut memiliki nilai spesifisitas tinggi. Tes asam fosfatase spesifik menunjukkan adanya enzim fosfatase, sedangkan tes zink spesifik menunjukkan adanya kandungan zink dalam semen. Enzim phosphohydrolase-fosfatase ini mudah mengalami degradasi karena faktor eksternal, antara lain temperature, kelembaban, dan bahan-bahan kimiawi, yaitu unsur SDS (Sodium Douducyl Sulfate) yang mempunyai kemampuan memotong-motong enzim. Kelemahan dari tes asam fosfatase adalah enzim ini mudah terdegradasi, baik parsial maupun total, karena faktor eksternal yakni suhu, kelembaban, panas, dan adanya bahan-bahan kimia.

Kata kunci: Efektivitas; acid phosphatase test; zink tes; identifikasi; bercak semen; persetubuhan

Correspondence: Ahmad Yudianto, Department of Forensic Medicine \& Medicolegal, Faculty of Medicine, Universitas Airlangga, Surabaya, Indonesia. E-mail: yudi4n6sby@yahoo.co.id 


\section{INTRODUCTION}

Identification to prove the presence of sperm is an absolute examination in cases of crime against decency, such as rape. One of examination methods that have the most positive diagnostic value is microscopic examination, because with the finding of spermatozoa, the spot/fluid clearly come sfrom semen (Yudianto 2020).

The presence of spermatozoa in vagina is a definite sign of sexual intercourse. However, sometimes microscopic examination finds no spermatozoa or reveals a false negative result. This is influenced by many factors, including the absence of ejaculate in the vagina. The other factors are oligo/azoospermia, vasectomy, sperm degeneration due to timing, incorrect sampling, and improper storage. Therefore, examination of the other components of the ejaculate, the enzyme acid phosphatase, choline, and spermin, is important. Compared with spermatozoa, the enzymes phosphatase, choline and spermin have lower evidentiary value because these three components are less specific. However, the levels of the enzyme phosphatase in the vagina is much lower compared to the level that comes from the prostate gland (Andrew et al 2000, Gefrides et al 2011).

Currently the examination method for preliminary identification has been developed. The first test used to identify stains of semen/spermatic fluid was by physical means with naked eye or by the help of ultraviolet light. This method is less accurate because it causes a lot of ultra violet fluorescence such as that in synthetic fiber goods, paints, washing materials and so on (Eckert 1980, Atmaja 1990, Gefrides \& Welch 2011)

Chemical testing is an alternative in the field of screening tests of sperm spot. Such chemical test is based on the difference in the concentration of a compound or enzyme in human semen: the presence or absence of spermatozoa (Hooft et al 1990, Susilawati 2011)

However, high enzyme concentration in human semen is not easily examined, because it requires several methods. A variety of examination techniques have been developed to date, including the Florence test and the Barberio test which are used in examinations to detect cholin or spermin (Yudianto 2013)

Another test, the Acid Phosphatase Test, is very sensitive (up to 64X dilution) and simple spot test, based on high concentrations of non-specific enzyme phophohydrolase-phosphatase acid derived from the prostate. This acid phosphatase test has a disadvantage that it has less specificity. Spots from plants such as cauliflowers, vaginal discharge, cosmetics, and spermicidal products can cause false positive reactions and their activity may decrease, either due to time or humidity around them (Yudianto 2013).

In 1983, Suzuki et al introduced a new method for identifying semen spots called the zinc test. This test is based on the fact that zinc concentration in human semen is much higher than that in other human body fluids or tissues at 5 to $23 \mathrm{mg} / 100 \mathrm{ml}$.

The acid phosphatase test and zinc test have a high sensitivity value as a screening for semen spot examination. However, more than $40 \%$ of the evidence of semen/sperm spots have sometimes been found to have undergone a change, either on purpose, such as washing, or due to accident, such as being wasted or immersed in water, and so on (Hafes 1976, Yudianto 2013).

Until now, the effectiveness of acid phosphatase test and zinc test in identifying human sperm spots that have been washed with various types of currently available detergents is still not widely known.

\section{MATERIALS AND METHODS}

This study was a laboratory experimental study. The samples were semen spots on cloths. Semen was obtained from a volunteer who agreed to participate in this study by providing informed consent. Then, the spots were made on cotton cloths measuring $10 \times 10 \mathrm{~cm}$ by dropping 1 drop each and dried at room temperature. Research materials: Reagent for zinc test: $10 \mathrm{mg}$ 1-(2pyridylazol)-2-naphtol dissolved in $2 \mathrm{ml}$ Triton X-100 and mixed with $98 \mathrm{ml} 0.5 \mathrm{M}$ Tris solution (6 grams (hydroxyl-methyl aminomethane in $100 \mathrm{ml}$ distilled water). The reagent was stored in a dark bottle in a refrigerator at 4 degrees $C$. Reagent for phosphatase test: Buffer in $90 \mathrm{ml}$ of distilled water plus 10 grams of $\mathrm{NaCl}, 0.5 \mathrm{ml}$ of glacial acetic acid, 1.5 grams of unhydrous sodium acetate, and $0.5 \mathrm{ml}$ Teepol. Fifty $\mathrm{mg}$ of Sodium Naphthyl-ortho-phosphate was dissolved in $25 \mathrm{ml}$ of buffer (1), $50 \mathrm{mg}$ of Diazo Blue B (ODianisidine) was dissolved in $25 \mathrm{ml}$ of buffer (1), then (2) and (3) were mixed and added with remaining buffer (1) After filtering, this mixture was stored in a dark bottle at 4 degrees C (Yudianto 2013). Washing ingredients (detergent): Ultra-soklin, Surf, Rinso, Attack, Daia, Lux, and Wings. 
Table 1. Test results with acid phosphatase test (TAF) and zinc test (TZ) on sperm spots after drying at room temperature for different times and washing with various detergents (Method I)

\begin{tabular}{|c|c|c|c|c|c|c|c|c|c|c|c|c|}
\hline \multirow{4}{*}{$\begin{array}{c}\text { Type of } \\
\text { detergent }\end{array}$} & \multicolumn{12}{|c|}{ Day of washing and examination } \\
\hline & \multicolumn{4}{|c|}{ Day 1} & \multicolumn{4}{|c|}{ Day 7} & \multicolumn{4}{|c|}{ Month 3} \\
\hline & \multicolumn{2}{|c|}{ TAF } & \multicolumn{2}{|c|}{$\mathrm{TZ}$} & \multicolumn{2}{|c|}{ TAF } & \multicolumn{2}{|c|}{$\mathrm{TZ}$} & \multicolumn{2}{|c|}{ TAF } & \multicolumn{2}{|c|}{$\mathrm{TZ}$} \\
\hline & $\mathrm{L}$ & TL & $\mathrm{L}$ & TL & $\mathrm{L}$ & TL & $\mathrm{L}$ & TL & $\mathrm{L}$ & TL & $\mathrm{L}$ & TL \\
\hline Ultra-soklin & $-(2)$ & $-(2)$ & $+(2)$ & $+(2)$ & $-(2)$ & $-(2)$ & $+(2)$ & $+(2)$ & $-(2)$ & $-(2)$ & $+(2)$ & $+(2)$ \\
\hline Surf & $-(2)$ & $-(2)$ & $+(2)$ & $+(2)$ & $-(2)$ & $-(2)$ & $+(2)$ & $+(2)$ & $-(2)$ & $-(2)$ & $+(2)$ & $+(2)$ \\
\hline Rinso & $-(2)$ & $-(2)$ & $+(2)$ & $+(2)$ & $-(2)$ & $-(2)$ & $+(2)$ & $+(2)$ & $-(2)$ & $-(2)$ & $+(2)$ & $+(2)$ \\
\hline Attack & $-(2)$ & $-(2)$ & $+(2)$ & $+(2)$ & $-(2)$ & $-(2)$ & $+(2)$ & $+(2)$ & $-(2)$ & $-(2)$ & $+(2)$ & $+(2)$ \\
\hline Daia & $-(2)$ & $-(2)$ & $+(2)$ & $+(2)$ & $-(2)$ & $-(2)$ & $+(2)$ & $+(2)$ & $-(2)$ & $-(2)$ & $-(2)$ & $-(2)$ \\
\hline Wing & $-(2)$ & $-(2)$ & $+(2)$ & $+(2)$ & $-(2)$ & $-(2)$ & $+(2)$ & $+(2)$ & $-(2)$ & $-(2)$ & $-(2)$ & $-(2)$ \\
\hline Lux & $+(2)$ & $+(2)$ & $+(2)$ & $+(2)$ & $-(2)$ & $-(2)$ & $+(2)$ & $+(2)$ & $-(2)$ & $-(2)$ & $-(2)$ & $-(2)$ \\
\hline Water (control) & $+(2)$ & $+(2)$ & $+(2)$ & $+(2)$ & $+(2)$ & $+(2)$ & $+(2)$ & $+(2)$ & $+(2)$ & $+(2)$ & $+(2)$ & $+(2)$ \\
\hline Total Sample & 16 & 16 & 16 & 16 & 16 & 16 & 16 & 16 & 16 & 16 & 16 & 16 \\
\hline
\end{tabular}

Note: M: Direct examination, TL: indirect examination using Whartman's filter paper $+:<30$ seconds, -:> 30 seconds

Table 2. Test results with acid phosphatase test (TAF) and zinc test (TZ) on sperm spots after drying and washing with various detergents, then examined in different periods (Method II)

\begin{tabular}{|c|c|c|c|c|c|c|c|c|c|c|c|c|}
\hline \multirow{4}{*}{ Type of detergent } & \multicolumn{12}{|c|}{ Day of examination } \\
\hline & \multicolumn{4}{|c|}{ Day 1} & \multicolumn{4}{|c|}{ Day 7} & \multicolumn{4}{|c|}{ Month 3} \\
\hline & \multicolumn{2}{|c|}{ TAF } & \multicolumn{2}{|c|}{$\mathrm{TZ}$} & \multicolumn{2}{|c|}{ TAF } & \multicolumn{2}{|c|}{$\mathrm{TZ}$} & \multicolumn{2}{|c|}{ TAF } & \multicolumn{2}{|c|}{$\mathrm{TZ}$} \\
\hline & $\mathrm{L}$ & $\mathrm{TL}$ & $\mathrm{L}$ & TL & $\mathrm{L}$ & $\mathrm{TL}$ & $\mathrm{L}$ & $\mathrm{TL}$ & $\mathrm{L}$ & $\mathrm{TL}$ & $\mathrm{L}$ & $\mathrm{TL}$ \\
\hline Ultra-soklin & $-(2)$ & $-(2)$ & $+(2)$ & $+(2)$ & $-(2)$ & $-(2)$ & $+(2)$ & $+(2)$ & $-(2)$ & $-(2)$ & $+(2)$ & $+(2)$ \\
\hline Surf & $-(2)$ & $-(2)$ & $+(2)$ & $+(2)$ & $-(2)$ & $-(2)$ & $+(2)$ & $+(2)$ & $-(2)$ & $-(2)$ & $+(2)$ & $+(2)$ \\
\hline Rinso & $-(2)$ & $-(2)$ & $+(2)$ & $+(2)$ & $-(2)$ & $-(2)$ & $+(2)$ & $+(2)$ & $-(2)$ & $-(2)$ & $+(2)$ & $+(2)$ \\
\hline Attack & $-(2)$ & $-(2)$ & $+(2)$ & $+(2)$ & $-(2)$ & $-(2)$ & $+(2)$ & $+(2)$ & $-(2)$ & $-(2)$ & $+(2)$ & $+(2)$ \\
\hline Daia & $-(2)$ & $-(2)$ & $+(2)$ & $+(2)$ & $-(2)$ & $-(2)$ & $+(2)$ & $+(2)$ & $-(2)$ & $-(2)$ & $+(2)$ & $+(2)$ \\
\hline Wing & $-(2)$ & $-(2)$ & $+(2)$ & $+(2)$ & $-(2)$ & $-(2)$ & $+(2)$ & $+(2)$ & $-(2)$ & $-(2)$ & $+(2)$ & $+(2)$ \\
\hline Lux & $-(2)$ & $-(2)$ & $+(2)$ & $+(2)$ & $-(2)$ & $-(2)$ & $+(2)$ & $+(2)$ & $-(2)$ & $-(2)$ & $+(2)$ & $+(2)$ \\
\hline Water & $+(2)$ & $+(2)$ & $+(2)$ & $+(2)$ & $+(2)$ & $+(2)$ & $+(2)$ & $+(2)$ & $+(2)$ & $+(2)$ & $+(2)$ & $+(2)$ \\
\hline Total samples & 16 & 16 & 16 & 16 & 16 & 16 & 16 & 16 & 16 & 16 & 16 & 16 \\
\hline
\end{tabular}

Note: M: Direct examination, TL: indirect examination using Whartman's filter paper $+:<30$ seconds, $-:>30$ seconds

Table 3. Screening test with zinc test and acid phosphatase test

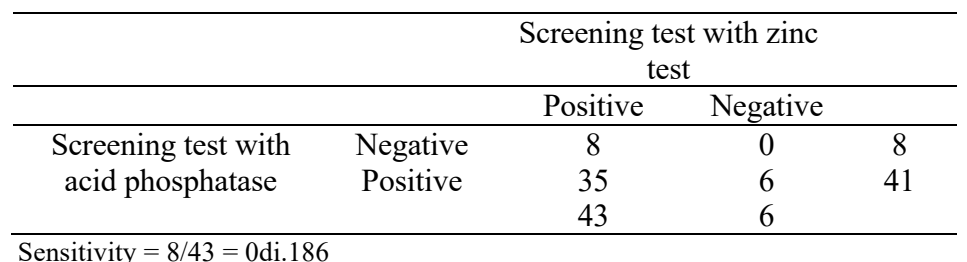

Sensitivity $=8 / 43=0$ di 186

Specificity $=6 / 6=1$

Positive predictive value $=8 / 8=1$

Negative predictive value $=6 / 41=0.146$

\section{RESULTS}

Table 1 shows that zinc test is more sensitive than acid phosphatase test in testing sperm spots that had been washed with various detergents. Table 2 shows clearly that zinc test is more resistant to the effects of washing with various detergents over a period of time than acid phosphatase test.

The assessment of the sensitivity and specificity of the two tests showed that both of the tests had very low sensitivity values while the specificity values were actually very high or absolute (1). This was possible due 
to the difference in screening detection between the phosphoric acid and zinc content in the semen.

\section{DISCUSSION}

This study found that zinc test was more resistant and sensitive to washing with various detergents compared to acid phosphatase test. In the first examination method, washing was carried out after drying at room temperature for one day, seven days and three months. Washing was carried out using 7 different brands of detergents sold in the market. The examination was carried out directly by spraying on cloths after washing, and indirectly by using wet Whartman filter paper which was affixed by pressing on the sample cloths that had been washed but had not been examined directly. Furthermore, the Whartman filter paper was sprayed with acid phosphatase test and zinc test. In the second method, after drying at room temperature, the sperm spots were then thoroughly washed together with various kinds of detergents. The results of washing were examined directly and indirectly on day 1 , day 7 , and month 3 .

Assessment of the measurement's validity in the screening tests was carried out by comparing the acid phosphatase test and the zinc test. The validity assessment was carried out using the concepts of sensitivity and specificity. Sensivity is the accuracy of the test to classify true positives in the subject. The higher the sensitivity value, the less the false negatives will be obtained. In this study, the sensitivity obtained was very low (0.186). This was due to differences in the value or detection points of the two tests. The acid phosphatase test is used on semen/sperm stains for their acid phosphatase content, while the zinc test is used for zinc content in sperm. Therefore, in azoospermic individuals whose semen does not contain sperm, the zinc test will be negative, but the acid phosphatase test will be positive.

Likewise, acid phosphatase, which in this case was the enzyme phosphohydrolase-phosphatase, is a product of the prostate gland. Abnormalities in the prostate gland can affect the quality and quantity of acid phosphatase in semen. In addition, acid phosphatase may originate from the production of glands in the vaginal area which are usually mixed in vaginal mucus. Intra-vaginal activity of semen acid phosphatase rapidly decreases due to dilution by vaginal secretions, changes in postcoital vaginal $\mathrm{pH}$, and disintegration, so qualitative determination of acid phosphatase alone is not sufficient to determine the presence or absence of sperm in the vagina. Therefore, it is necessary to make quantitative determination (Yudianto 2005, Sham 2006).
This phosphohydrolase-phosphatase enzyme is easily degraded due to external factors, including temperature, humidity and chemicals. This chemical effect is the presence of SDS (Sodium Dodecyl Sulfate) which has the ability to cut enzymes, and is exacerbated by the presence of linear alkylbenzene sulfonate (LAS) preparation element which has two groups, the alkyl group $(\mathrm{CH} 3)$ and the sulfonate group $(\mathrm{SO} 3 \mathrm{H})$, which has hydrophilic and hydrophobic properties, able to bind impurities such as grease or oil as they are able to emulsify both (Sham 2006, L Gefrides \& Welch 2011, Terrence 2013).

In the examination, zinc test is based on the zinc content or organic ionic substances whose levels are high in semen, especially human sperm $(140 \mathrm{mg} / \mathrm{ml})$ which appear more stable. Because it is an organic ionic material, it does not degrade, either due to temperature, humidity or chemical influences, and will also stick firmly to objects. This zinc test also does not produce false positives, which is usually the case with acid phosphatase tests which can produce false positives from plants such as cauliflower and vaginal mucus (Gefrides \& Welch 2011).

The color generated in this reaction was pink, which was a reaction of 1-(2-pyridylazo)-2-naphtol (PAN) with zinc to form chelate (pink colored solution). If the testing uses test tube or in a porcelain basin, the color that appears will be dark red. Therefore, for practical purpose, acid phosphatase test is superior, because by spraying the reagent on a cloth or Whartman filter paper, it produces more contrasting colors. When the zinc test is done by spraying, the color that appears will be pink, which is not very contrasting (Andrew $\mathrm{G}$ et al, 2000).

Therefore, the specificity values of zinc test and acid phosphatase test were very valid $(100 \%)$. This study shows that increasing specificity will decrease sensitivity of a screening test. It is generally because screening test not only clearly shows which subjects are categorized as normal and which are abnormal, but also shows which subjects are in gray zone or borderline area. Therefore, the classification is only made dichotomous, so it depends on the cut-off point chosen. Subjects at borderline can be categorized as normal or, conversely, abnormal. More specifically, if we loosen the criteria for positivity, the subjects at borderline will tend to be classified as true positives. Conversely, if we tighten the criteria for positivity, then the subjects at borderline will tend to be classified as true negative. 


\section{CONCLUSION}

The sensitivity values of zinc test and acid phosphatase test are low (0.186), while their specificity values are $100 \%$. The weakness of acid phosphatase test is that it uses an enzyme that is easily degraded, either partially or completely, due to external factors, such as temperature, humidity, heat and chemistry. The presence of detergents can result in enzyme degradation by SDS and LAS preparations they contain.

\section{REFERENCES}

Atmaja DS, et al (1990). Tes zink (PAN) dan tes asam fosfatase untuk identifikasi bercak sperma manusia. Majalah Kedokteran Indonesia 40, 198-203

Eckert WG (1980). Introduction to forensic sciences. St. Louis, The CV Mosby Co

Gefrides L, Welch K (2011). Forensic Biology: Serology and DNA in A Mozayani, C Nozigilia (Eds). The Forensic Laboratory Handbook Procedures and Practice. Humana Press., p 15-50

Hafes ESE (1976). Human semen and fertility regulation in men. Saint Louis, The CV Mosby Co, p $596-600$
Hooft et al (1990). The zinc test as an alternative for acid phospahatse spot test in the primary identification of seminal traces. Forensic Sciene International 47, 269-275

Murti B (1997). Prinsip dan metode riset epidemiologi. UGM Press, $p$ 63-66

Sham DB (2006). Properties of deterjent (Amphiles). Univeritas of texas health center at tyler. Available at www.syche.uthct.edu/shaun/s.black/deterjent.html. Accessed December 16, 2006

Susilawati T (2011). Spermatology. Universitas Brawijaya Press, p 3-36

Suzuki OA, Kido M, Oya (1983). Zinc test as a new tool for identification for human seminal stains. Forensic Science International 2, 231-235

Terrence FK (2013). Forensic Evidence, CRC Press

Yudianto A (2005). Dampak pencucian bercak darah dengan deterjent pada tes darah samara sebagai screening test. Tugas akhir PPDS Ilmu kedokteran forensic \& Medikolegal FK Unair

Yudianto A (2013). Panduan Praktis Serologi Forensik. Penerbit Global Persada Press, p 83-100

Yudianto A (2020) Ilmu Kedokteran Forensik. Scopindo Media Pustaka, p 139-145 